\title{
ANALISIS FAKTOR YANG BERPENGARUHTERHADAP PERNIKAHAN DINI DESA BALIMBINGAN KECAMATAN TANAH JAWA KABUPATEN SIMALUNGUN
}

\author{
Doren Lestari Sagala ${ }^{1}$, Mappeaty Nyorong ${ }^{2}$, Endang Marianti ${ }^{3}$ \\ 1,2,3 Institut Kesehatan Helvetia, Medan \\ Email: Lestarisagala099@gmail.com
}

\begin{abstract}
Abstrak
Pernikahan usia dini menurut Undang-undang No.16 tahun 2019 adalah pernikahan yang dilakukan oleh perempuan dibawah usia 19 tahun. Tujuan penelitian untuk menganalisis faktor-faktor apa saja yang berpengaruh terhadap pernikahan usia dini di Desa Balimbingan Kecamatan Tanah Jawa Kabupaten Simalungun.Jenis penelitian ini dengan pendekatan kuantitatif dan kualitatif (Mixed Methods) dengan menggunakan desain case control. Sampel dalam penelitian ini berjumlah 84 responden. 42 responden kasus dan 42 responden kontrol. Instrumen yang digunakan yaitu kuesioner. Analisis data dilakukan secara univariat dan bivariat dengan uji chi-square, dan multivariat dengan uji regresi logistik berganda pada tingkat kepercayaan $95 \%(\alpha=0,05)$. Data kualitatif melalui data reduction, data display, conclusion drawing, dan verification. Hasil penelitian didapatkan bahwa faktor yang berpengaruh dengan pernikahan usia dini adalah faktorpendidikan responden $(p$-value $=0,000) \mathrm{OR}=9,342$, faktor pengetahuan $(p$-value $=0,000), \mathrm{OR}=3,333$, ekonomi orangtua $(p$-value $=0,000) \mathrm{OR}=44,615$, dan faktor yang tidak berpengaruh dengan pernikahan usia diniialahkepercayaanbudaya ( $p$-value $=0,063) \mathrm{OR}=6,667$ pola asuh $(p$-value $=0,424) \mathrm{OR}=3,200$. Variabel dominan atau variabel yang paling besar pengaruhnya terhadap pernikahan dini dalam penelitian ini adalah variabel ekonomi mempunyai nilai $\mathrm{OR}=44,615$ artinya maka perempuan yang memiliki orang tua dengan ekonomi rendah berisiko 44 kali melakukan pernikahan usia dini dibandingkan dengan perempuan yang memiliki ekonomi tinggi.Kesimpulan penelitian bahwa pendidikan, pengetahuan, ekonomiberpengaruh terhadap pernikahan usai dini. Disarankan kepada KUA agar memberikan informasi kepada pasangan baru terkait dampak pernikahan usia dini, selain itu untuk masyarakat yaitu pemberian informasi pendidikan kesehatan bagi remaja.
\end{abstract}

Kata Kunci : Pernikahan usia dini, pendidikan, pengetahuan, ekonomi, kepercayaan, pola asuh orangtua

\begin{abstract}
According to Undang-undang No.16 year 2019, early marriage is a marriage carried out by women under the age of 19 years. The purpose of the study was to analyze the factors that influence early marriage in Balimbingan Village, Tanah Jawa District, Simalungun Regency. This type of research uses a quantitative and qualitative approach (Mixed Methods) using a case control design. The sample in this study amounted to 84 respondents. 42 case respondents and 42 control respondents. The instrument used is a questionnaire. Data analysis was carried out univariate and bivariate with chi-square test, and multivariate with multiple logistic regression test at 95\% confidence level $(\alpha=0.05)$. Qualitative data through data reduction, data display, conclusion drawing, and verification. The results showed that the factors that influence early marriage are the respondent's education factor $(p$-value $=0.000)$ OR $=9.342$, knowledge factor $(p$-value $=0.000), O R=3.333$, parents' economy ( $p$-value $=0.000) O R=44,615$, and the factor that has no effect on early marriage is cultural beliefs ( $p$-value $=0.063) O R=6.667$ parenting style $(p$-value $=0.424)$ OR $=3.200$. The dominant variable or the variable that has the greatest influence on early marriage in this study is the economic variable which has an OR value of 44,615, meaning that women who have parents with low economic status are 44 times more likely to marry at an early age than women who have a high economy. The conclusion of the study is that education, knowledge, economy have an effect on early marriage. It is recommended to KUA to provide information to new couples regarding the impact of early marriage, in addition to the community, namely providing information on health education for adolescents.
\end{abstract}


Keywords: Early marriage, education, knowledge, economy, trust, parenting

\section{Pendahuluan}

Pernikahan adalah ikatan lahir dan batin antara seorang pria dengan seorang wanita sebagai suami-istri dengan tujuan membentuk keluarga yang sejahtera. Keluarga sejahtera diartikan sebagai unit terkecil dalam masyarakat yang terdiri dari suami atau istri dengan anaknya. Tujuan membangun keluarga yang sejahtera yaitu keluarga yang bahagia yang dibentuk berdasarkan atas perkawinan yang sah, dimana keluarga mampu memenuhi kebutuhan hidup spiritual maupun materi yang layak, bertaqwa kepada Tuhan Yang Maha Esa, memiliki hubungan yang serasi, selaras dan seimbang antar anggota dengan masyarakat dan lingkungan.

Menurut Undang-undang No.16 tahun 2019 batasan usia pernikahan yang dilakukan oleh seorang laki-laki dengan usia minimal 19 tahun dan usia minimal wanita19 tahun (Sitorus, 2019). Namun kenyataannya masih banyak masyarakat yang melakukan pernikahan pada usia dibawah 19 tahun. Faktanya berdasarkan data United Nations Children's Fund (UNICEF) tahun 2019 terdapat sekitar 115 juta anak laki-laki yang menikah si bawah usia 18 tahun. Satu dari lima anak-anak itu menikah sebelum mereka 15 tahun. UNICEF mengatakan dengan temuan itu, berarti sekarang ada 765 juta anak lakilaki dan perempuan menikah di antara 2,2 miliar anak secara global, tetapi bagi anak perempuan akan ada tambahan resiko masalah kesehatan yang berkaitan dengan kehamilan di usia remaja.

Penyebab dari pernikahan dini di Indonesia dipengaruhi oleh banyak faktor, antara lain pendidikan yang rendah, kebutuhan ekonomi, kultur nikah muda, sikap seks pranikah dan pemahaman agama (Judiasih, 2018). Penelitian di oleh M.Fadhil (2020) juga menyatakan bahwa faktor yang menyebabkan pernikahan dibawah umur di Desa Jelutih Kecamatan Batin XXIV Kabupaten Batang Hari yakni adanya faktor lingkungan atau kebiasaan menikah muda, adanya kasus hamil diluar nikah, ekonomi karena kurangnya penghasilan yang didapat sehingga banyak anak yang tidak sekolah dan mengharuskan mereka segera menikah (Fadhil, 2020).

Perkawinan usia remaja berdampak pada rendahnya kualitas keluarga, baik ditinjau dari segi ketidaksiapan secara psikis dalam menghadapi persoalan sosial maupun ekonomi rumah tangga (Judiasih, 2018). Serta memicu terjadinya kekerasan dalam rumah tangga (Burns, 2016). Selain itu, pernikahan usia dini berdampak buruk bagi kesehatan ibu sejak hamil sampai melahirkan maupun bayi karena organ reproduksi yang belum sempurna. Belum matangnya organ reproduksi menyebabkan perempuan yang menikah usia dini berisiko terhadap berbagai penyakit seperti kanker serviks, perdarahan, keguguran, mudah terjadi infeksi saat hamil, anemia saat hamil, resiko terkena pre eklampsia dan persalinan yang lama dan sulit. Sedangkan dampak pernikahan dini pada bayi berupa premature, Berat Bayi Lahir Rendah (BBLR), cacat bawaan hingga kematian bayi (Manuaba, 2009).

Berdasarkan survei awal yang dilakukan oleh peneliti pada tanggal 20 November 2019 di desa Balimbingan Kecamatan Tanah Jawa Kabupaten Simalungun, disana banyak anak yang berusia dibawah umur sudah menikah. Hal ini disebabkan karena beberapa faktor diantaranya faktor adat atau kebiasaan, para orang tua beranggapan bahwa pendidikan tidak terlalu penting terutama untuk perempuan karena mereka beranggapan bahwa perempuan pada akhirnya tempatnya didapur juga. Kemudian faktor ekonomi di Desa ini banyak anak yang ingin melanjutkan pendidikan kejenjang yang lebih tinggi tetapi terkendala dengan biaya, karena orang tua mereka untuk makan saja susah apa lagi untuk 
biaya pendidikan. Mereka dinikahkan untuk mencegah terjadinya zinah tetapi mereka juga tidak mengetahui pengaruh pernikahan di usia muda dengan kesehatan terutama kesehatan reproduksi terutama pada remaja putri mereka sehingga mereka memilih untuk menikahkan anaknya pada usia dini.

Berdasarkan uraian dan data diatas peneliti tertarik melakukan penelitian dengan judul analisis faktor yang berpengaruh terhadap pernikahan dini di desa Balimbingan Kecamatan Tanah Jawa Kabupaten Simalungun Tahun 2019.

\section{Metode Penelitian}

Penelitian ini yang digunakan adalah metode penelitian Mix Method. Diterapkan dengan pengumpulan data dan analisis data kuantitatif (kuesioner) pada tahap pertama yang diikuti oleh pengumpulan dan analisi data kualitatif yang dibangun berdasarkan hasil awal kuantitatif yang dilakukan dengan wawancara.

Populasi yang digunakan dalam penelitian ini adalah perempuan yang menikah pada usia dini dalam kurun waktu lima tahun terakhir (2015-2020) yaitu 42 perempuan. Teknik pengambilan sampel dalam penelitian ini dilakukan dengan total sampling yaitu 42 responden kasus dan 42 responden kontrol. Sampel pada penelitian kualitatif adalah orang yang telah ditentukan oleh peneliti untuk memberikan informasi tentang situasi dan kondisi latar belakang penelitian. Metode Pengumpulan data kuantitatif Data Primer diperoleh secara langsung dari responden melalui kuesioner yang dilakukan dengan wawancara langsung kepada responden, data Sekunder data atau dukungan yang diperoleh dari data desa Balimbingan, data Tersier data yang diperoleh dari berbagai referensi yang valid seperti jurnal dan Data WHO. Metode pengumpulan data kualitatif dilakukan dengan In-depth Interview (wawancara mendalam) kepada informan dengan menggunakan pedoman wawancara dan pertanyaan-pertanyaan yang secara umum tidak terstruktur (unstructured) dan bersifat terbuka (open-ended) sebagai panduan yang dirancang untuk memunculkan pandangan dan opini dari para informan atau partisipan. Selanjutnya peneliti melakukan observasi terhadap informan. Analisis univariat dilakukan terhadap tiap variabel (variabel bebas dan variabel terikat), yaitu tingkat pengetahuan,pendidikan,ekonomi, polaasuh orang tua, dan kepercayaan terhadap pernikahan usia dini. Hasil analisis berupa distribusi dan persentase dari tiap variabel disajikan dalam bentuk tabel. Dalam analisis ini uji statistik yang digunakan adalah chi-square. Syarat uji chi-square adalah tidak ada sel dengan nilai observedexpected kurang dari 5 maksimal 20\% dari jumlah sel. Jika syarat uji chi-square tidak terpenuhi, maka uji alternatifnya: Alternatif uji chisquare untuk tabel $2 \times 2$ adalah uji fisher. Alternatif uji chi-square untuk tabel $2 \times \mathrm{K}$ adalah uji Kolmogorof-Smirnov. Alternatif uji chi-square untuk tabel selain 2x 2 dan 2 x K adalah uji penggabungan sel. 


\section{Hasil dan Pembahasan}

Berdasarkan penelitian diperoleh distribusi data responden berdasarkan usia respondenkasus dan kontrol yang di sajikan dalam tabel sebagai berikut:

Tabel 4.1. DistribusiUsia Responden Kasus dan Kontrol

\begin{tabular}{ccc}
\hline Usia & frekuensi & \% \\
\hline $\mathbf{1 4}$ & 1 & 1,2 \\
$\mathbf{1 5}$ & 2 & 2,4 \\
$\mathbf{1 6}$ & 5 & 6,0 \\
$\mathbf{1 7}$ & 14 & 16,7 \\
$\mathbf{1 8}$ & 20 & 23,8 \\
$\mathbf{2 0}$ & 12 & 14,3 \\
$\mathbf{2 1}$ & 13 & 15,5 \\
$\mathbf{2 2}$ & 10 & 11,9 \\
$\mathbf{2 3}$ & 2 & 2,4 \\
$\mathbf{2 4}$ & 4 & 4.8 \\
$\mathbf{2 5}$ & 1 & 1,2 \\
\hline Total & 84 & 100 \\
\hline
\end{tabular}

Berdasarkan tabel 4.1. Distribusi usia responden kasus diketahui bahwa usia menikah pertama yaitu 14 tahun sebanyak 1 responden dengan persentase $1,2 \%$, usia 15 tahun sebanyak 2 responden dengan persentase $2,4 \%$, usia16 tahun sebanyak 5 responden dengan persentase $6,0 \%$, usia 17 tahun sebanyak 14 responden dengan persentase $16,7 \%$, usia18 tahun sebanyak 20 responden dengan persentase $23,8 \%$, Distribusi usia responden kontrol, usia menikah pertama yaitu 20 tahun sebanyak responden 12 dengan persentase $14,3 \%$, usia 21 tahun sebanyak 13 responden dengan persentase $15,5 \%$, usia 22 tahun sebanyak 10 responden dengan persentase $11,9 \%$, usia 23 tahun sebanyak 2 responden dengan persentase $2,4 \%$, usia 24 tahun sebanyak 4 responden dengan persentase $4,8 \%$, usia 25 tahun sebanyak 1 respondendenganpersentase $1,2 \%$.

Tabel 4.2. Tabel Distribusi Pendidikan Responden Kasus dan Kontrol

\begin{tabular}{|c|c|c|c|c|c|}
\hline \multirow[t]{3}{*}{ Pendidikan } & & & & & \multirow[t]{3}{*}{ Jumlah } \\
\hline & \multicolumn{2}{|c|}{ Kasus } & \multicolumn{2}{|c|}{ Kontrol } & \\
\hline & $\mathrm{n}$ & $\%$ & $\mathrm{n}$ & $\%$ & \\
\hline Dasar & 24 & 57,1 & 1 & 2,3 & 25 \\
\hline Lanjut & 18 & 42,9 & 41 & 97,7 & 59 \\
\hline Jumlah & 42 & 100 & 42 & 100 & 84 \\
\hline
\end{tabular}

Berdasarkan Tabel 4.2. Distribusi pendidikan responden kasus dengan pendidikan dasar sebanyak 24 responden dengan persentase $57,1 \%$, dan pendidikan lanjut sebanyak 18 responden dengan persentase $42,9 \%$, Distribusi pendidikan responden control dengan pendidikan dasar sebanyak 1 responden dengan persentase $2,3 \%$, dan pendidikan lanjut sebanyak 41 responden dengan persentase $97,7 \%$.

\section{Distribusi Pengetahun Kasus dan Kontrol}

Tabel 4.3. Tabel Distribusi Pengetahuan Responden Kasus dan Kontrol

\begin{tabular}{|c|c|c|c|c|c|}
\hline \multirow[t]{3}{*}{ Pengetahuan } & & & & & \multirow[t]{3}{*}{ Jumlah } \\
\hline & \multicolumn{2}{|c|}{ Kasus } & \multicolumn{2}{|c|}{ Kontrol } & \\
\hline & $\mathbf{n}$ & $\%$ & $\mathbf{n}$ & $\%$ & \\
\hline Cukup & 24 & 57,1 & 0 & 0 & 24 \\
\hline Baik & 18 & 42,9 & 42 & 100 & 60 \\
\hline Jumlah & 42 & 100 & 42 & 100 & 84 \\
\hline
\end{tabular}


Berdasarkan Tabel 4.3. Distribusi pengetahuan responden kasus dengan pengetahuan cukup sebanyak 24 responden dengan persentase $57,1 \%$, dan pendidikan lanjut sebanyak 18 responden dengan persentase $42,9 \%$, Distribusi pengetahuan responden control dengan pengetahuan baik sebanyak 42 responden dengan persentase $100 \%$.

\section{Distribusi Ekonomi Kasus dan Kontrol}

Tabel 4.4. TabelDistribusi Ekonomi Responden Kasus dan Kontrol

\begin{tabular}{cccccc}
\hline Ekonomi & \multicolumn{3}{c}{ Kontrol } & Jumlah \\
\cline { 2 - 5 } & \multicolumn{2}{c}{ Kasus } & $\mathbf{n}$ & \% & \\
\cline { 2 - 5 } & $\mathbf{n}$ & $\mathbf{\%}$ & 13 & 30,9 & 53 \\
\hline Rendah & 40 & 95,2 & 29 & 69,1 & 31 \\
\hline Tinggi & 2 & 4,8 & 42 & 100 & 84 \\
\hline Jumlah & 42 & 100 & n & & \\
\hline
\end{tabular}

Berdasarkan Tabel 4.4. Distribusi ekonomi responden kasus dengan ekonomi rendah sebanyak 40 responden dengan persentase $95,2 \%$, dan ekonomi tinggi sebanyak 2 responden dengan persentase 4,8\%, Distribusi ekonomi responden control dengan ekonomi rendah sebanyak 13 responden dengan persentase 30,9\%, dan ekonomi tinggi sebanyak 29 responden dengan persentase $69,1 \%$.

\section{Distribusi Kepercayaan Budaya Kasus dan Kontrol}

Tabel 4.5. TabelDistribusi Kepercayaan Responden Kasus dan Kontrol

\begin{tabular}{cccccc}
\hline Kepercayaan & \multicolumn{3}{c}{ Kontrol } & Jumlah \\
\cline { 2 - 5 } & \multicolumn{2}{c}{ Kasus } & n & \% & \\
\cline { 2 - 6 } & $\mathbf{n}$ & 57,1 & 7 & 16,7 & 31 \\
\hline Percaya & 24 & 42,9 & 35 & 83,3 & 53 \\
\hline Tidak Percaya & 18 & 100 & 42 & 100 & 84 \\
\hline Jumlah & 42 & &
\end{tabular}

\section{Distribusi Pola Asuh Orang Tua Kasus dan Kontrol}

Tabel 4.6. Tabel Distribusi Pola Asuh Orang tua Responden Kasus dan Kontrol

\begin{tabular}{lccccc}
\hline \multirow{2}{*}{$\begin{array}{l}\text { Pola Asuh Orang } \\
\text { Tua }\end{array}$} & \multicolumn{3}{c}{ Kasus } & \multicolumn{3}{c}{ Kontrol } & Jumlah \\
\cline { 2 - 6 } & $\mathbf{n}$ & $\mathbf{\%}$ & $\mathbf{n}$ & $\mathbf{\%}$ & \\
\hline Otoriter & 32 & 76,1 & 21 & 50 & 53 \\
\hline Non-Otoriter & 10 & 23,9 & 21 & 50 & 31 \\
\hline Jumlah & 42 & 100 & 42 & 100 & 84 \\
\hline
\end{tabular}

\section{Analisis Bivariat}

Untuk menguji hubungan variable bebas dengan variabel terikat digunakan uji Chi-square dan untuk mengetahui besar faktor resiko digunakan analisis Odds Ratio (OR). Berdasarkan hasil penelitian di desa Balimbingan Kecamatan Tanah Jawa Kabupaten Simalungun diperoleh hasil analisis bivariat dari masing-masing faktor risiko kejadian pernikahan usia dini pada kasus dan control sebagaiberikut.

\section{Hubungan Antara Pendidikan Responden dengan Pernikahan Usia Dini}

Untuk mengetahui hubungan antara pendidikan responden dengan pernikahan usia dini dapat dilihat dalam tabel berikut ini:

Tabel 4.7 Crostab Hubungan antara Pendidikan dengan Pernikahan Usia Dini 


\section{MIRACLE JOURNAL}

\begin{tabular}{ccccccc}
\hline Pendidikan & \multicolumn{2}{c}{ Kasus } & \multicolumn{2}{c}{ Kontrol } & p-value & OR \\
\cline { 2 - 5 } & $\mathrm{n}$ & $\%$ & $\mathrm{n}$ & $\%$ & & (LL-UL) \\
\hline Dasar & 24 & 57,1 & 1 & 2,3 & 0,000 & 9,342 \\
Lanjut & 18 & 42,9 & 41 & 97,7 & & $(6,859-435,710)$ \\
\hline Total & 42 & 100 & 42 & 100 & & \\
\hline
\end{tabular}

Hasil uji hubungan tersebut memenuhi syarat untuk uji menggunakan Chi-Square karena tidak terdapat sel dengan nilai observed nol (0) dan nilai dengan expected (E) kurang dari 5, maksimal 20\% dari jumlah sel. Dengan taraf kepercayaan 95\% diperoleh hasil $p$ value $0,000(<0,05)$ sehingga Ho diterima dan Ha ditolak, artinya ada hubungan yang bermakna antara pendidikan respon den terhadap pernikahan dini di desa Balimbingan kecamatan Tanah Jawa Kabupaten Simalungun.

\section{Hubungan Antara Pengetahuan Responden dengan Pernikahan Dini}

Untuk mengetahui hubungan antara pengetahuan responden dengan pernikahan usia dini dapat dilihat dalam tabel berikut ini:

Tabel 4.8 Crostab Hubungan antara Pengetahuan dengan Pernikahan Usia Dini

\begin{tabular}{|c|c|c|c|c|c|c|}
\hline \multirow[t]{2}{*}{ Pengetahuan } & \multicolumn{2}{|c|}{ Kasus } & \multicolumn{2}{|c|}{ Kontrol } & \multirow[t]{2}{*}{$p$-value } & \multirow{2}{*}{$\begin{array}{c}\text { OR } \\
\text { (LL-UL) }\end{array}$} \\
\hline & $\mathrm{n}$ & $\%$ & $\mathrm{n}$ & $\%$ & & \\
\hline Cukup & 24 & 57,1 & 0 & 0 & 0,000 & 3,333 \\
\hline Baik & 18 & 42,9 & 42 & 100 & & $(2,265-4,906)$ \\
\hline Total & 42 & 100 & 42 & 100 & & \\
\hline
\end{tabular}

Hasil uji hubungan tersebut memenuhi syarat untuk uji menggunakan Chi-Square karena tidak terdapat sel dengan nilai observed nol (0) dan nilai dengan expected (E) kurang dari 5, maksimal 20\% dari jumlah sel. Dengan taraf kepercayaan 95\% diperoleh hasil $p$ value $0,000(<0,05)$ sehingga Ho diterima dan Ha ditolak, artinya ada hubungan yang bermakna antara pengetahuan responden terhadap pernikahan dini di desa Balimbingan kecamatan Tanah Jawa Kabupaten Simalungun.

\section{Hubungan Antara Ekonomi Responden dengan Pernikahan Usia Dini}

Variabel ekonomi memiliki 2 kategori yakni ekonomi rendah dan ekonomi tinggi. Untuk mengetahui hubungan antara ekonomi responden dengan pernikahan usia dini dapat dilihat dalam tabel berikut ini:

Tabel 4.9 Crostab Hubungan antara ekonomi dengan Pernikahan Usia Dini

\begin{tabular}{ccccccc}
\hline Ekonomi & \multicolumn{2}{c}{ Kasus } & \multicolumn{2}{c}{ Kontrol } & p-value & OR \\
\cline { 2 - 5 } & $\mathrm{n}$ & $\%$ & $\mathrm{n}$ & $\%$ & & (LL-UL) \\
\hline Rendah & 40 & 95,2 & 13 & 30,9 & 0,000 & 44,615 \\
Tinggi & 2 & 4,8 & 29 & 69,1 & & $(9,342-213,074)$ \\
\hline Total & $\mathbf{4 2}$ & $\mathbf{1 0 0}$ & $\mathbf{4 2}$ & $\mathbf{1 0 0}$ & & \\
\hline
\end{tabular}

Hasil uji hubungan tersebut memenuhi syarat untuk uji menggunakan Chi-Square karena tidak terdapat sel dengan nilai observed nol (0) dan nilai dengan expected (E) kurang dari 5, maksimal 20\% dari jumlah sel. Dengan taraf kepercayaan $95 \%$ diperoleh hasil $p$ value $0,000(<0,05)$ sehingga Ho diterima dan Ha ditolak, artinya ada hubungan yang bermakna antara ekonomi responden terhadap pernikahan dini di desa Balimbingan kecamatan Tanah Jawa Kabupaten Simalungun.

\section{Hubungan Antara Kepercayaan Budaya Responden dengan Pernikahan Usia Dini}

Variabel kepercayaan memiliki 2 kategori yakni percaya dan tidak percaya. Untuk mengetahui hubungan antara kepercayaan responden dengan pernikahan usia dini dapat dilihat dalam tabel berikut ini: 
Tabel 4.10 Crostab Hubungan antara kepercayaan dengan Pernikahan Usia Dini

\begin{tabular}{|c|c|c|c|c|c|c|}
\hline \multirow{2}{*}{$\begin{array}{c}\text { Kepercayaan } \\
\text { budaya }\end{array}$} & \multicolumn{2}{|c|}{ Kasus } & \multicolumn{2}{|c|}{ Kontrol } & \multirow[t]{2}{*}{ p-value } & \multirow{2}{*}{$\begin{array}{c}\mathbf{O R} \\
(\mathrm{LL}-\mathrm{UL})\end{array}$} \\
\hline & $\mathrm{n}$ & $\%$ & $\mathrm{n}$ & $\%$ & & \\
\hline Percaya & 24 & 57,1 & 7 & 16,7 & 0,000 & 6,667 \\
\hline Tidak Percaya & 18 & 42,9 & 35 & 83,3 & & $(2,414-18,412)$ \\
\hline Total & 42 & 100 & 42 & 100 & & \\
\hline
\end{tabular}
karena tidak terdapat sel dengan nilai observed nol (0) dan nilai dengan expected (E) kurangdari 5, maksimal 20\% dari jumlah sel. Dengan taraf kepercayaan 95\% diperoleh hasil $p$ value $0,000(<0,05)$ sehingga Ho diterima dan Ha ditolak, artinya ada hubungan yang bermakna antara kepercayaan responden terhadap pernikahan dini di desa Balimbingan kecamatan Tanah Jawa Kabupaten Simalungun.

\section{Hubungan Antara Pola Asuh Orang Tua dengan Pernikahan Usia Dini}

Untuk mengetahui hubungan antara pola asuh orang tua dengan pernikahan usia dini dapat dilihat dalam tabel berikut ini:

Tabel 4.11 Crostab Hubungan antara Pola Asuh Orang Tua dengan Pernikahan Usia Dini

\begin{tabular}{|c|c|c|c|c|c|c|}
\hline \multirow[t]{2}{*}{ Pola Asuh } & \multicolumn{2}{|c|}{ Kasus } & \multicolumn{2}{|c|}{ Kontrol } & \multirow[t]{2}{*}{$p$-value } & \multirow{2}{*}{$\begin{array}{c}\mathbf{O R} \\
(\mathrm{LL}-\mathrm{UL})\end{array}$} \\
\hline & $\mathrm{n}$ & $\%$ & $\mathrm{n}$ & $\%$ & & \\
\hline Otoriter & 32 & 76,1 & 21 & 50 & 0,023 & 3,200 \\
\hline Non-Otoriter & 10 & 23,9 & 21 & 50 & & $(1,259-8,133)$ \\
\hline Total & 42 & 100 & 42 & 100 & & \\
\hline
\end{tabular}

Berdasarkan table 4.11 hasil analisa hubungan antara pola asuh orang tua dengan pernikahan usia dini diperoleh hasil bahwa dari 42 responden kasus, sebanyak 32 responden dengan persentase $76,1 \%$ responden dengan pola asuh otoriter, sebanyak 10 dengan persentase $23,9 \%$ dengan pola asuh non-otoriter. Dari 42 responden kontrol, sebanyak 21 responden dengan persentase $50 \%$ responden dengan pola asuh otoriter, sebanyak 21 responden dengan persentase 50\% dengan pola asuh non-otoriter.

Hasil uji hubungan tersebut memenuhi syarat untuk uji menggunakan Chi-Square karena tidak terdapat seldengan nilai observed nol (0) dan nilai dengan expected (E) kurang dari 5, maksimal 20\% dari jumlah sel. Dengan taraf kepercayaan 95\% diperoleh hasil $p$ value $0,023(<0,05)$ sehingga Ho diterima dan Ha ditolak, artinya ada hubungan yang bermakna antara pola asuh orang tua terhadap pernikahan dini di desa Balimbingan kecamatan Tanah Jawa Kabupaten Simalungun.

\section{Analisis Multivariat}

Analisis multivariat dilakukan untuk mengetahui faktor yang berpengaruh terhadap pernikahan dini menggunakan uji regresi logistik berganda (multiple logistic regression) melalui beberapa langkah:

1. Melakukan pemilihan variabel yang potensial dimasukkan sebagai kandidat model. Variabel yang dipilih sebagai kandidat adalah variabel yang memiliki nilai signifikan.

2. Dalam pemodelan ini variabel kandidat yang memiliki nilai $p$-value $<0,05$ pada uji bivariat (uji chi-square) dimasukkan secara bersama-sama dalam uji multivariat.

3. Penggunaan kemaknaan statistik 0,05 sebagai persyaratan dalam uji regresi logistik berganda untuk memungkinkan variabel-variabel yang secara terselubung sesungguhnya secara substansi sangat penting dimasukkan ke dalam model multivariat. 
4. Hasil analisis bivariat menggunakan uji chi-square, sebanyak 5 variabel yang dijadikan kandidat model pada uji regresi logistik berganda pada penelitian ini karena memiliki nilai signifikan $<0,05$ yaitupengetahuan $(0,000)$, pendidikan $(0,000)$, ekonomi $(0,000)$, kepercayaan $(0,000)$,sertapolaasuh orang tua $(0,023)$.

5. Selanjutnya dilakukan pengujian dengan regresi logistik berganda secara bersamaan dengan metode forward conditional untuk mengidentifikasi faktor paling berpengaruh terhadappernikahandini. Metode forward conditional yaitu memasukkan satu per satu variabel dari hasil pengkorelasian variabel dan memenuhi kriteria kemaknaan statistik untuk masuk ke dalam model, sampai semua variabel yang memenuhi kriteria tersebut masuk ke dalam model. Variabel yang masuk pertama kali adalah variabel yang mempunyai korelasi parsial terbesar dengan variabel dependen dan yang memenuhi kriteria tertentu untuk dapat masuk model.

Tabel 4.12. Hasil Uji Regresi Logistik Ganda

\begin{tabular}{lccccc}
\hline \multirow{2}{*}{ Variabel } & \multirow{2}{*}{$\mathrm{B}$} & \multirow{2}{*}{ Sig } & OR & \multicolumn{2}{c}{$95 \%$ C for EXP $(\mathrm{B})$} \\
\cline { 5 - 6 } & & & & Lower & Upper \\
\hline Pendidikan & 0,454 & 0,000 & 9,342 & 6,859 & 453,710 \\
Pengetahuan & 0,565 & 0,000 & 3,333 & 2,265 & 4,906 \\
Ekonomi & 0,252 & 0,000 & 44,615 & 9,342 & 213,074 \\
Kepercayaan budaya & 0,114 & 0,063 & 6,667 & 2,414 & 18,412 \\
Pola asuh & 0,026 & 0,424 & 3,200 & 1,259 & 8,133 \\
\hline
\end{tabular}

Variabel dominan atau variabel yang paling besar pengaruhnya terhadap pernikahan dini dalam penelitian ini adalah variabel ekonomi mempunyai nilai $\mathrm{OR}=$ 44,615 artinya orang tua dengan ekonomi rendah 44 kali lebih memungkinkan untuk menikahkan anaknya pada usia dini dibandingkan dengan orang tua dengan ekonomi tinggi.

Variabel pendidikan mempunyai nilai $\mathrm{OR}=9,342$ artinya responden dengan pendidikan dasar berpeluang 9,34 kali lebih besar melakukan pernikahan dini dibandingkan dengan respon den berpendidikan lanjut. Variabel pengetahuan mempunyai nilai $\mathrm{OR}=3,333$ artinya responden dengan pengetahun cukup berpeluang 3,3 kali lebih besar melakukan pernikahan dini dibanding dengan responden yang memiliki pengetahuan baik. Variabel kepercayaan mempunyai nilai $\mathrm{OR}=6,667$ artinya responden yang percaya dengan pernikahan dini berpeluang 6,6 kali melakukan pernikahan dini disbanding dengan responden yang tidak percaya terhadap pernikahan dini.

Hasil uji regresi logistik yang dilakukan dengan menggabungkan semua hasil yang mempunyai hubungan signifikan dengan pernikahan dini didapatkan dari semua variable terdapat 3 variabel yang memiliki pengaruh terhadap pernikahan dini, yakni pendidikan, pengetahuan, ekonomi. Dan 2 variabel yang tidak memiliki pengaruh terhadap pernikahan dini, yakni kepercayaan dan pola asuh orang tua.

\section{Hasil Penelitian Kualitatif Karakteristik Informan}

Informan penelitian ini diambil sebanyak 7 orang yang sudah mewakili dari masalah penelitian yang diteliti. Informan terdiri dari informan utama (3 orang wanita yang melakukan pernikahan dini), informan kunci (1 orang tokoh adat), dan informan tambahan 3 orang yaitu orang tua dari pasangan pernikahan dini. Adapun karakteristik dari ketujuh informan tersebut adalah sebagai berikut :

Tabel 4.13. Karakteristik Informan Penelitian

\begin{tabular}{llcccccc}
\hline No & $\begin{array}{l}\text { Inisial } \\
\text { informan }\end{array}$ & Umur & $\begin{array}{c}\text { Jenis } \\
\text { Kelamin }\end{array}$ & Pendidikan & Pekerjaan & Suku & Agama \\
\hline 1. & Ny. W & 18 & Perempuan & SD & IRT & Jawa & Islam \\
\hline
\end{tabular}




\begin{tabular}{|c|c|c|c|c|c|c|c|}
\hline 2. & Ny. S & 18 & Perempuan & SD & IRT & Mandailing & Islam \\
\hline 3. & Ny. M & 19 & Perempuan & SMP & IRT & Jawa & Kristen \\
\hline 4. & Ny. H & 18 & Perempuan & SMP & $\begin{array}{c}\text { Karyawan } \\
\text { swasta }\end{array}$ & Jawa & Kristen \\
\hline 5. & Ny. I & 35 & Perempuan & SD & Petani & Jawa & Islam \\
\hline 6. & Ny. N & 40 & Perempuan & SD & Buruh & Batak & Islam \\
\hline 7. & Ny. SM & 51 & Perempuan & SMP & Petani & Batak & Islam \\
\hline 8. & Ny. D & 40 & Perempuan & $\mathrm{SD}$ & IRT & Jawa & Islam \\
\hline 9. & Tn. P & 47 & Laki-laki & SMA & Petani & Jawa & Kristen \\
\hline 10. & Tn. S & 49 & Laki-laki & SMA & Petani & Jawa & Islam \\
\hline 11. & Tn. I & 55 & Laki-laki & SMA & Wiraswasta & Jawa & Islam \\
\hline 12. & Ny. E & 31 & Perempuan & D3 & Perawat & Batak & Kristen \\
\hline
\end{tabular}

Tabel 4.13 di atas menunjukkan bahwa dari kedua belas informan, berjenis kelamin laki-laki sebanyak 3 orang dan perempuan sebanyak 9 orang. Rentang umur responden dari 18 tahun sampai 55 tahun. Berdasarkan jenjang pendidikan, 5 orang berpendidikan SD, 3 orang berpendidikan SMP, 3 orang berpendidikan SMA dan 1 orang berpendidikan diploma-3. Berdasarkan pekerjaan, 4 orang bekerja sebagai IRT, 4 orang bekerja sebagai petani, 1 orang bekerja sebagai buruh, 1 orang bekerja sebagai wiraswasta, 1 orang bekerja sebagai karyawan swasta dan 1 orang bekerja sebagai perawat. Berdasarkan suku, 8 orang bersuku jawa, 3 orang bersuku batak dan 1 orang bersuku mandailing. Berdasarkan agama, 8 orang beragama islam dan 4 orang beragama Kristen.

\section{Faktor yang mempengaruhi terjadinya pernikahan dini}

\section{Pengetahuan}

Hasil wawancara dengan informan berkaitan dengan pengetahuan informan tentang pernikahan dini dapat dilihat pada table berikut ini:

Tabel 4.14. Matriks hasil wawancara dengan informan tentang pengetahuan tentang pernikahan dini

\begin{tabular}{|c|c|}
\hline Informan & Hasil Wawancara \\
\hline $\begin{array}{l}\text { Informan } 1 \\
(\mathrm{Ny} . \mathrm{W})\end{array}$ & $\begin{array}{l}\text { "kalau menurut saya ya dek, pernikahan dini itu, nikahnya dibawah } \\
17 \text { tahun kali ya" }\end{array}$ \\
\hline $\begin{array}{l}\text { Informan } 2 \\
\text { (Ny. S) }\end{array}$ & $\begin{array}{l}\text { "nikah dini sama kayak nikah muda kan dek, menurut saya } \\
\text { nikahnya dibawah } 17 \text { tahun" }\end{array}$ \\
\hline $\begin{array}{l}\text { Informan } 3 \\
\text { (Ny.M) }\end{array}$ & "nikah dini itu nikah dibawah 17 tahun kak" \\
\hline $\begin{array}{l}\text { Informan } 4 \\
\text { (Ny.H) }\end{array}$ & $\begin{array}{l}\text { "nikah dini sama kayak nikah muda kan ya kak, menurut saya nikah } \\
\text { muda itu nikah dibawah } 17 \text { tahun" }\end{array}$ \\
\hline $\begin{array}{l}\text { Informan } 5 \\
\text { (Ny.I) }\end{array}$ & "nikah dini ya nikah dibawah 17 tahun. Iya kan.." \\
\hline $\begin{array}{l}\text { Informan } 6 \\
(\mathrm{Ny} . \mathrm{N})\end{array}$ & "nikah dibawah 17 tahun mungkin ya" \\
\hline $\begin{array}{l}\text { Informan } 7 \\
\text { (Ny. SM) }\end{array}$ & "nikah dini itu nikah sebelum tamat SMA kali ya, 17 tahun mungkin" \\
\hline $\begin{array}{l}\text { Informan } 8 \\
(\mathrm{Ny} . \mathrm{D})\end{array}$ & "nikahnya dibawah 15 tahun" \\
\hline $\begin{array}{l}\text { Informan } 9 \\
\text { (Tn.P) }\end{array}$ & "pernikahan yang nikahnya dibawah 17 tahun" \\
\hline $\begin{array}{l}\text { Informan } 10 \\
\quad(\text { Tn. S) }\end{array}$ & "pernikahan dini itu pernikahan dibawah 20 tahun" \\
\hline $\begin{array}{l}\text { Informan } 11 \\
\quad(\text { Tn. I) }\end{array}$ & $\begin{array}{l}\text { "pernikahan dibawah } 25 \text { tahun untuk laki-laki dan dibawah } 23 \text { tahun } \\
\text { untuk perempuan" }\end{array}$ \\
\hline $\begin{array}{l}\text { Informan } 12 \\
\quad(\mathrm{Ny} . \mathrm{E})\end{array}$ & $\begin{array}{l}\text { "pernikahan dini itu pernikahan dibawah usia } 19 \text { tahun baik untuk } \\
\text { pria maupun wanita" }\end{array}$ \\
\hline
\end{tabular}




\section{Ekonomi}

Hasil wawancara dengan informan berkaitan dengan ekonomi informan tentang pernikahan dini dapat dilihat pada table berikut ini.

Tabel4.15. Matriks hasil wawancara dengan informan tentang ekonomi tentang pernikahan dini

\begin{tabular}{|c|c|}
\hline Informan & Hasil Wawancara \\
\hline $\begin{array}{c}\text { Informan } 1 \\
(\mathrm{Ny} . \mathrm{W})\end{array}$ & $\begin{array}{l}\text { "ya namanya udah gak sekolah, ngapain lama-lama juga nganggur } \\
\text { yakan, pacar siap ngelamar. Yaudah nikah" }\end{array}$ \\
\hline $\begin{array}{l}\text { Informan } 2 \\
(\mathrm{Ny} . \mathrm{S})\end{array}$ & "liat orang tua kasihan. Biar gak jadi beban orang tua aja" \\
\hline $\begin{array}{l}\text { Informan } 3 \\
\text { (Ny.M) }\end{array}$ & $\begin{array}{l}\text { "karna udah jodoh kali ya. Kalau udah ketemu jodoh ngapan lama- } \\
\text { lama yakan, toh udah nggak sekolah lagi. Putus sekolah waktu SMP } \\
\text { soalnya kak" }\end{array}$ \\
\hline $\begin{array}{l}\text { Informan } 4 \\
\text { (Ny.H) }\end{array}$ & $\begin{array}{l}\text { "saya udah nggak sekolah.nggak ada biaya dulu, Udah kerja juga. } \\
\text { Selain itu kawan-kawan saya juga udah banyak yang nikah" }\end{array}$ \\
\hline $\begin{array}{l}\text { Informan } 5 \\
\qquad \text { (Ny.I) }\end{array}$ & $\begin{array}{l}\text { "ada. Soalnya suami saya udah ninggal, jadi saya banting tulang } \\
\text { besarin anak-anak saya. Jadi waktu anak saya minta nikah, saya } \\
\text { dukung banget. Setidaknya saya udah nggak mikirin dia lagi"” }\end{array}$ \\
\hline $\begin{array}{l}\text { Informan } 6 \\
(\mathrm{Ny} . \mathrm{N})\end{array}$ & $\begin{array}{l}\text { "ada. Karna nggak punya uang juga, mau makan aja susah, payah } \\
\text { cakap lah dek" }\end{array}$ \\
\hline $\begin{array}{l}\text { Informan } 7 \\
(\text { Ny. SM) }\end{array}$ & $\begin{array}{l}\text { "ada. Kan udah saya bilang tadi, ngak sanggup saya nyekolahinnya } \\
\text { karna suami saya juga kerja gak kerja" }\end{array}$ \\
\hline $\begin{array}{l}\text { Informan } 8 \\
\text { (Ny. D) }\end{array}$ & $\begin{array}{l}\text { "ada. Besar banget pengaruhnya, karena semua tergantung uang } \\
\text { kan" }\end{array}$ \\
\hline $\begin{array}{l}\text { Informan } 9 \\
\text { (Tn.P) }\end{array}$ & $\begin{array}{l}\text { "ekonomi bisa, karna gak sekolah lagi, atau karna sudah hamil } \\
\text { duluan" }\end{array}$ \\
\hline $\begin{array}{l}\text { Informan } 10 \\
\quad(\text { Tn. S) }\end{array}$ & $\begin{array}{l}\text { "paling banyak mungkin karena faktor keuangan atau ekonomi ya, } \\
\text { putus sekolah, dan hamil diluar nikah" }\end{array}$ \\
\hline $\begin{array}{l}\text { Informan } 11 \\
\qquad(\mathrm{Tn} . \mathrm{I})\end{array}$ & $\begin{array}{l}\text { "ya banyak ya, bisa karena ekonomi, hamil diluar nikah, pengaruh } \\
\text { media sosial seperti facebook dan apalagi sekarang ada tiktiok, } \\
\text { makin gak karuan lah anak zaman sekarang ini" }\end{array}$ \\
\hline $\begin{array}{l}\text { Informan } 12 \\
(\mathrm{Ny} . \mathrm{E})\end{array}$ & $\begin{array}{l}\text { "salah satu faktor yang terbesar yaitu masalah ekonomi, pergaulan } \\
\text { teman sebaya dan media sosial saya rasa dek" }\end{array}$ \\
\hline
\end{tabular}

\section{Kepercayaan Budaya}

Hasil wawancara dengan informan berkaitan dengan kepercayaan budaya informan tentang pernikahan dini dapat dilihat pada table berikut ini.

Tabel 4.16. Matriks hasil wawancara dengan informan tentang kepercayaan budaya tentang pernikahan dini

\begin{tabular}{cc}
\hline Informan & Hasil Wawancara \\
\hline Informan 1 & "Lumayan banyak memang kak yang nikah muda disini. Kayaknya \\
(Ny. W) & bukan karna budaya sih ya, tapi karna keterpaksaan kondisi aja" \\
Informan 2 & "kayaknya biasa aja ya, nggak ada masalah juga kan kalau nikah \\
(Ny. S) & muda" \\
Informan 3 & "biasa aja. Paling jadi bahan omongan seminggu aja" \\
(Ny.M) & "kayaknya biasa aja sih kak, waktu aku nikah dulu justru para \\
Informan 4 & keluarga pada dukung, karna kan nikah cepet bias menghindari \\
(Ny.H) & "oinah juga kan" \\
Informan 5 & "kayaknya masih ada ya, soalnya karna kondisi di sini sih yang \\
(Ny.I) & bikin"
\end{tabular}




\section{MIRACLE JOURNAL}

\begin{tabular}{cc}
\hline Informan & Hasil Wawancara \\
\hline Informan 7 & "bukan budaya mungkin namanya ya dek, cuman ya karna faktor \\
(Ny. SM) & ekonomi, terpaksalah" \\
Informan 8 & "keterpaksaan kali ya namanya, namanya juga nggak punya duit lagi \\
(Ny. D) & untuk buat sekolah" \\
Informan 9 & "saya ada ya. Karna kalau lama nikah suka di bilang perawan tua \\
(Tn.P) & atau kadang karna anak melihat kondisi orang tuanya sih, yang \\
& makan aja susah" \\
Informan 10 & "kalau menurut agama tidak ada batasan usia menikah seorang \\
(Tn. S) & perempuan dek. Tapi karena kebiasaan disini ya begitu. Kalau udah \\
Informan 11 & nggak sekolah lagi biasanya cepet nikah" \\
(Tn. I) & ini "Yapi kalau disini udah kayak budaya mungkin yang nikah muda \\
Informan 12 & "salah satu faktor yang terbesar yaitu masalah ekonomi, dan udah \\
(Ny. E) & karena jadi kebiasaan lingkungan juga pergaulan teman sebaya dan \\
& media sosial saya rasa dek"
\end{tabular}

\section{Pola Asuh Orang tua}

Hasil wawancara dengan informan berkaitan dengan polaasuh orang tua informan tentang pernikahan dini dapat dilihat pada tabel berikut ini.

Tabel 4.17. Matriks hasil wawancara dengan informan tentang pengetahuan tentang pernikahan

\begin{tabular}{|c|c|}
\hline Informan & $\begin{array}{ll}\text { Hasil Wawancara } \\
\end{array}$ \\
\hline $\begin{array}{c}\text { Informan } 1 \\
(\mathrm{Ny} . \mathrm{W})\end{array}$ & $\begin{array}{l}\text { "Bapak saya itu slalu nyuruh saya ini, itu tanpa nanya ke saya. Saya } \\
\text { nya mau nggak, saya nya suka nggak. Nggak pernha ditanya itu kak. } \\
\text { Bapak saya emang keras. Jadi Ibu saya pun nggak bisa bilang apa- } \\
\text { apa" }\end{array}$ \\
\hline $\begin{array}{l}\text { Informan } 2 \\
(\text { Ny. S })\end{array}$ & $\begin{array}{l}\text { "kayaknya ada juga sih, saya nggak begitu dekat dengan orang tua } \\
\text { saya. Soalnya dulu tinggal di rumah nenek waktu kecil. Setelah } \\
\text { nenek ninggal, yaudah balek ke rumah orang tua. Jadi nggak begitu } \\
\text { dekat dan saya pun kurang terbuka mengenai apa yang saya } \\
\text { rasakan" }\end{array}$ \\
\hline $\begin{array}{l}\text { Informan } 3 \\
\text { (Ny.M) }\end{array}$ & "kayaknya nggak sih. Saya memang pengen nikah muda aja” \\
\hline $\begin{array}{l}\text { Informan } 4 \\
(\mathrm{Ny} \cdot \mathrm{H})\end{array}$ & $\begin{array}{l}\text { "saya dari kecil udah nggak punya orang tua kak. Saya tinggal sama } \\
\text { keluarga dari ibu saya. Tante. Kayaknya nggak sih. Soalnya tante } \\
\text { saya membebaskan saya untuk mengambil keputusan untuk hidup } \\
\text { saya" }\end{array}$ \\
\hline $\begin{array}{l}\text { Informan } 5 \\
\quad(\text { Ny.I })\end{array}$ & $\begin{array}{l}\text { "kadang iya. Kadang juga nggak. Lagian kita orang tua pasti } \\
\text { memberikan yang terbaik untuk anak kan.." }\end{array}$ \\
\hline $\begin{array}{l}\text { Informan } 6 \\
(\mathrm{Ny} . \mathrm{N})\end{array}$ & $\begin{array}{l}\text { "kadang ya namanya kita orang tua, kita ngerasa kita yang paling } \\
\text { benar. Namanya orang tua pasti mau yang terbaik untuk anaknya. } \\
\text { Kadang saya Tanya juga maunya apa, tapi tetap saya yang } \\
\text { menentukan kesimpulannya" }\end{array}$ \\
\hline $\begin{array}{l}\text { Informan } 7 \\
(\text { Ny. SM) }\end{array}$ & $\begin{array}{l}\text { "boleh, tapi tetap saya dan suami yang mengambil keputusan apapun } \\
\text { itu” }\end{array}$ \\
\hline $\begin{array}{l}\text { Informan } 8 \\
\text { (Ny. D) }\end{array}$ & $\begin{array}{l}\text { " kadang iya, kadang enggak. Tapi segala keputusan yang } \\
\text { menentukan ya orang tuanya juga" }\end{array}$ \\
\hline
\end{tabular}

Berdasarkan hasil penelitian menunjukkan bahwa terdapat pengaruh antara pendidikan terhadap pernikahan dini di Desa Balimbingan Kecamatan Tanah Jawa Kabupaten Simalungun tahun 2019 dengan nilai $p$-value $=0,000$. Nilai OR=9,342, maka 
perempuan yang memiliki pendidikan dasar berisiko 9,3 kali melakukan pernikahan usia dini dibandingkan dengan perempuan yang memiliki pendidikan lanjut.

Penelitian ini juga diperkuat dengan penelitian yang dilakukan oleh Kanella Ayu Wulandari, Anggi Napida A, dan Suparman yang menyatakan bahwa variable pendidikan responden memiliki hubungan dengan pernikahan dini pada wanita yang dibuktikan dengan $p$-value pada uji chi-square didapatkan $p$-value sebesar $0,035(p<0,05)$ (Wulandari, 2016).

Berdasarkan hasil observasi data yang didapatkan pada saat penelitian yaitu sebagian besar pendidikan terakhir responden kasus yang melakukan pernikahan usia dini yaitu lulus sekolah menengah pertama (SMP), dimana rata-rata usia ketika remaja baru lulus menempuh pendidikan sekolah menengah pertama (SMP) yaitu usia 16 sampai 17 tahun. Menurut Undang-Undang no 20 tahun 2003 pendidikan sekolah menengah pertama merupakan pendidikan yang termasuk kategori pendidikan dasar. Sedangkan pendidikan pada responden kontrol yaitu sebagian besar responden dengan pendidikan terakhir sekolah menengah atas dan perguruan tinggi. Dalam undang-undang pendidikan, sekolah menengah atas (SMA) merupakan kategori pendidikan menengah dan perguruan tinggi merupakan kategori Pendidikan Tinggi.

Berdasarkan data peneliti dari 42 responden kasus terdapat $57,1 \%$ dengan pendidikan dasar dan 42,9\% lainnya memiliki pendidikan lanjut tetapi tidak hingga tamat SMA. Sehingga peneliti berkesimpulan semakin rendah pendidikan responden, makaakan cenderung melakukan pernikahan dini. Hal ini kemungkinan terjadi karena responden dengan tingkat pendidikan rendah cenderung sulit untuk menerima informasi.

Berdasarkan hasil penelitian menunjukkan bahwa terdapat pengaruh antara pengetahuan terhadap pernikahan dini di Desa Balimbingan Kecamatan Tanah Jawa Kabupaten Simalungun tahun 2019 dengan nilai $p$-value $=0,000$. Nilai $\mathrm{OR}=3,333$, maka perempuan yang memiliki pengetahuan kurang berisiko 3,33 kali melakukan pernikahan usia dini dibandingkan dengan perempuan yang memiliki pengetahuan baik.

Penelitian ini juga diperkuat dengan penelitian yang dilakukan oleh Nazli Halawani Pohan (2017) menyatakan bahwa remaja putrid dengan pengetahuan kurang mempunyai resiko 6,192 kali menikah dini disbanding remaja putri yang berpengetahuan baik (Pohan, 2017). Hasil penelitianini juga sejalan dengan penelitian Dwinanda (2016) yang menyatakan bahwa responden yang memiliki pengetahuan rendah mengenai pernikahan dini memiliki resiko 4,286 kali dari pada responden yang memiliki pengetahuan tinggi mengenai pernikahan usia dini (95\% CI: 2,082-8,825) (Dwinanda, 2017).

Dari hasil penelitian terdapat 24 responden dengan pengetahuan cukup dan 18 responden dengan pengetahuan baik. Dari hasil wawancara peneliti dengan informan mengenai pengetahuan mereka tentang pernikahan dini, dominan masih minim pengetahuan tentang pernikahan dini, hasil wawancara peneliti dengan informan yang melakukan pernikahan dini "kalau menurut saya ya dek, pernikahan dini itu, nikahnya dibawah 17 tahun kali ya"(Informan 1, "nikah dini sama kayak nikah muda kan dek, menurut saya nikahnya dibawah 17 tahun"(Informan 2), "nikah dini itu nikah dibawah 17 tahun kak"(Informan 3), "nikah dini sama kayak nikah muda kan ya kak, menurut saya nikah muda itu nikah dibawah 17 tahun"(Informan 4).Hal ini disebabkan karena kebanyakan responden hanya lulus sekolah formal sampai dengan sekolah menengah pertama. Dengan demikian dapat disimpulkan bahwa pengetahuan seseorang mempengaruhi pola pikir responden dalam membuat keputusan didalam hidupnya.

Berdasarkan hasil penelitian menunjukkan bahwa terdapat pengaruh antara ekonomi terhadap pernikahan dini di Desa Balimbingan Kecamatan Tanah Jawa Kabupaten Simalungun tahun 2019 dengan nilai $p$-value $=0,000$. Nilai $\mathrm{OR}=44,615$, maka perempuan yang memiliki orang tua dengan ekonomi rendah berisiko 44,61 kali melakukan pernikahan usia dini dibandingkan dengan perempuan yang memiliki ekonomi tinggi. 
Hasil penelitian menunjukan bahwa sebagian responden yang melakukan pernikahan usia dini salah satunya karena di sebabkan oleh faktor ekonomi. Sebagian dari mereka memutuskan untuk menikah bukan karena dari dirinya masing-masing, ada sebagian karena keputusan orangtua. Orangtua menganggap bahwa mereka tidak mampu untuk menyekolahkannnya dengan demikian orangtua memutuskan untuk menikahkan anaknya karena dianggap dapat meringankan beban orangtua. Dari hasil wawancara terhadap orang tua informan utama, didapat bahwa ada pengaruh ekonomi terhadap keputusan mereka menikahkan anaknya pada usia dini "ada. Soalnya suami saya udah ninggal, jadi saya banting tulang besarin anak-anak saya. Jadi waktu anak saya minta nikah, saya dukung banget. Setidaknya saya udah nggak mikirin dia lagi"'(Informan 5), "ada. Karna nggak punya uang juga, mau makan aja susah, payah cakap lah dek”(Informan 6), "ada. Kan udah saya bilang tadi, ngak sanggup saya nyekolahinnya karna suami saya juga kerja gak kerja”(Informan 7), "ada. Besar banget pengaruhnya, karena semua tergantung uang kan"(Informan 8), "ekonomi bisa, karna gak sekolah lagi, atau karna sudah hamil duluan"'(Informan 9), pengaruh media sosial seperti facebook dan apalagi sekarang ada tiktiok, makin gak karuan lah anak zaman sekarang ini"'(Informan $11)$.

Berdasarkan hasil penelitian menunjukkan bahwa terdapat pengaruh antara kepercayaan terhadap pernikahan dini di Desa Balimbingan Kecamatan Tanah Jawa Kabupaten Simalungun tahun 2019 dengan nilai $p$-value $=0,063$.Nilai $\mathrm{OR}=6,667$, maka perempuan yang memiliki kepercayaan terhadap penikahan dini berisiko 6,66 kali melakukan pernikahan usia dini dibandingkan dengan perempuan yang tidak percaya dengan pernikahan dini.

Menurut peneliti, dari kuesioner yang disebarkan ke responden diketahui bahwa sebagian besar wanita di Desa Balimbingan percaya bahwa kebudayaan yang mempengaruhi kejadian pernikahan dini karena kedewasaan seseorang dinilai dari status perkawinan. Jika wanita tersebut lama menikah maka akan dianggap sebagai perawan tua. Menikahk anak pada usia dini dapat meringankan beban ekonomi keluarga. Dari hasil wawancara dengan informan dilapangan didapat hasil bahwa mereka tidak menganggap bahwa mereka yang menikah dini bukan karena budaya melainkan karena keterpaksaan atau karena kondisi ekonomi yang mendorong untuk melakukan pernikahan dini, “ Lumayan banyak memang kak yang nikah muda disini. Kayaknya bukan karna budaya sih ya, tapi karna keterpaksaan kondisi aja”(informan 1), "kayaknya biasa aja sih kak, waktu aku nikah dulu justru para keluarga pada dukung, karna kan nikah cepet bisa menghindari zinah juga kan"(Informan 4), "bukan budaya mungkin namanya ya dek, cuman ya karna faktor ekonomi, terpaksalah" (Informan 7), Sehingga dapat disimpulkan bahwa semakin tinggi kepercayaan dari pengaruh kebudayaan di desa tersebut maka semakin besar wanita yang melakukan pernikahan dini.

Berdasarkan hasil penelitian menunjukkan bahwa tidak terdapat pengaruh antara pola asuh terhadap pernikahan dini di Desa Balimbingan Kecamatan Tanah Jawa Kabupaten Simalungun tahun 2019 dengan nilai $p$-value $=0,424$. Nilai $\mathrm{OR}=3,200$ maka perempuan yang memiliki pola asuh otoriter berisiko 3,2 kali melakukan pernikahan usia dini dibandingkan dengan perempuan dengan pola asih non-otoriter.

Menurut peneliti, dari kuesioner yang disebarkan ke responden diketahui bahwa sebagian besar wanita di Desa Balimbingan yang melangsungkan pernikahan dini tidak semua memiliki tingkat kedewasaan/kematangan yang ideal. Meningat keluarga adalah tempat pertama bagi tumbuh kembangnya anak sejak lahir hingga dewasa maka pola asuh anak dalam keluarga perlu disebarluaskan pada setiap keluarga. Dari hasil wawancara terhadap orang tua informan utama, didapat bahwa setiap orang tua memiliki caranya sendiri untuk mengasuhan aknya, "kadang iya. Kadang juga nggak. Lagian kita orang tua pasti memberikan yang terbaik untuk anak kan.. "(Informan 5), "kadang ya namanya kita 
orang tua, kita ngerasa kita yang paling benar. Namanya orang tua pasti mau yang terbaik untuk anaknya. Kadang saya Tanya juga maunya apa, tapi tetap saya yang menentukan kesimpulannya"(Informan 6), "boleh, tapi tetap saya dan suami yang mengambil keputusan apapun itu”(informan 7), " kadang iya, kadang enggak. Tapi segala keputusan yang menentukan ya orang tuanya juga"(informan 8). Sehingga peneliti menyimpulkan bahwa tidak ada pengaruh pola asuh orang tua terhadap penikahan dini.

\section{Kesimpulan}

Berdasarkan hasil penelitian yang telah dilakukan dan disajikan pembahasan pada bab sebelumnya dapat disimpulkan bahwa : Pendidikan berpengaruh terhadap pernikahan dini di Desa Balimbingan Kecamatan Tanah Jawa Kabupaten Simalungun, $p$ value $=0,000$, Pengetahuan berpengaruh terhadap pernikahan dini di Desa Balimbingan Kecamatan Tanah Jawa Kabupaten Simalungun, $p$-value $=0$,000, Ekonomi berpengaruh terhadap pernikahan dini di Desa Balimbingan Kecamatan Tanah Jawa Kabupaten Simalungun, $p$-value $=0,000$, Kepercayaan budaya tidak berpengaruh terhadap pernikahan dini di Desa Balimbingan, Kabupaten Simalungun, $p$-value $=0,063$, Pola asuh tidak berpengaruh terhadap pernikahan dini di Desa Balimbingan Kecamatan Tanah Jawa Kabupaten Simalungun, $p$-value $=0,672$, Variabel dominan atau variabel yang paling besar pengaruhnya terhadap pernikahan dini dalam penelitian ini adalah variabel ekonomi mempunyai nilai $\mathrm{OR}=44,615$ artinya maka perempuan yang memiliki orang tua dengan ekonomi rendah berisiko 44,61 kali melakukan pernikahan usia dini dibandingkan dengan perempuan yang memiliki ekonomi tinggi.

\section{DAFTAR PUSTAKA}

Agustinova DE. (2015). Memahami Metode Penelitian Kualitatid. Calpulis.

Burns AA. (2016). Pemberdayaan Wanita dalam Bidang Kesehatan. I. Achmad dr. J, editor. Yogyakarta: ANDI.

Dwinanda AR, Wijayanti AC, Werdani KE. (2017). Hubungan Antara Pendidikan Ibu Dan Pengetahuan Responden Dengan Pernikahan Usia Dini. J Kesehat Masy Andalas.

Fadhil. (2020). Faktor Penyebab Pernikahan Di Bawah Umur Terhadap Kelanjutan Pendidikan Di Desa Jelutih Kecamatan Batin XVIV Kabupaten Batang Hari Provinsi Jambi.

Judiasih SD. (2018). Pernikahan bawah umur Indonesia. Summayah D, editor. Bandung: REFIKA.

Laporan Badan Koordinasi Keluarga Berencana Nasional. Usia Pernikahan ideal 21-25 tahun. 2017.

Manuaba IA. (2009). Memahami Kesehatan Reproduksi Wanita. Edisi 2. Jakarta: EGC.

Muhammad I. (2016). Pemanfaatan SPSS dalam penlitian Bidang Kesehatan dan Umum. Cita Pustaka Media Perintis.

Pohan NH. (2017). Faktor Yang Berhubungan Dengan Pernikahan Usia Dini Terhadap Remaja Putri. J Endur.

Sitorus IR. (2019) Batasan usia perkawinan yang ditetapkan oleh pemerintah Indonesia. (16):190-9.

UNICEF. (2019) Child marriage is a violation of human rights, but is all too common. www.data.unicef.org.

Wulandari KA. (2016). Faktor-faktor yang berhubungan dengan pernikahan dini di dusun Gading Banjarnegara. Rev Bras Geogr Física. Laporan Badan Koordinasi Keluarga 


\section{MIRACLE JOURNAL \\ MIRACLE JOURNAL \\ e-ISSN 2774 - 4663 \\ Vol 2, No 1, Januari 2022}

Berencana Nasional. Usia Pernikahan ideal 21-25 tahun. 2017. 